\title{
A Comparative Social Enterprise Analysis: Motives, Processes and Barriers
}

\author{
Fatih Öztürk*
}

\begin{abstract}
Social entrepreneurship is a model that has a significant impact on the social transformation process. It has emerged as an effective and complementary method of achieving social change which has been poorly interpreted by governments and businesses. Today, many social enterprises are established to develop innovative solutions for catering to essential human needs. In this paper, emerging processes, advancements and organizational concepts of some social enterprises are reviewed in detail. This review puts forward that each of social initiatives has diverse dimensions, features, barriers and issues. Therefore, this article offers a comparative analysis identifying strengths and weaknesses of the social entrepreneurship model at the organizational level.
\end{abstract}

Keywords: social enterprise, poverty, social change, barriers.

Submitted: 31.08.2014 | Accepted: 01.10.2014

\section{Analiza porównawcza przedsiębiorstw społecznych - motywy, procesy i bariery}

Przedsiębiorczość spoteczna jest modelem, który ma znaczacy wptyw na proces transformacji spotecznej. Okazała się ona skuteczna i dopetniajaca metoda doprowadzenia do zmian społecznych, która byta mato zrozumiała dla rząów i przedsiębiorstw. Obecnie wiele przedsiębiorstw spotecznych ma na celu opracowanie innowacyjnych rozwiazań zaspokajajacych podstawowe potrzeby człowieka. W artykule przeprowadzono szczegótowa analizę pojawiajacych się procesów, osiagnięć $i$ koncepcji organizacyjnych kilku przedsiębiorstw spotecznych. Założono, że każda inicjatywa spoteczna ma różnorakie wymiary, cechy, bariery i problemy. Dlatego też zaprezentowano analizę porównawcza wskazująca mocne i stabe strony modelu przedsiębiorczości spotecznej na poziomie organizacyjnym.

Słowa kluczowe: przedsiębiorstwo społeczne, ubóstwo, zmiana społeczna, bariery.

Nadesłany: 31.08.2014 | Zaakceptowany do druku: 01.10.2014

JEL: M13, A13

\footnotetext{
* Fatih Öztürk - Uniwersytet Warszawski, Wydział Zarządzania.

Adres do korespondencji: Uniwersytet Warszawski, Wydział Zarządzania UW, ul. Szturmowa 1/3, 02-678 Warszawa; e-mail: fatihozturk@gmail.com.
} 
In any culture or tradition, attention is given to ideas and initiatives that can address social problems and create ideal states. This is because humans and their activities are central to societies and social problems arising in societies are mostly related to human behaviors and choices. Therefore, answers and solutions to social issues are typically found by people themselves. When these solutions are implemented in needy social classes, the results reveal whether the solutions are well executed, useful and applicable. In this regard, today, it is globally acknowledged that one of the most significant models for social transformation is social entrepreneurship. Its broad perspective, innovative approach and social aspect locate it in an extraordinary position. Hence, it attracts the interest of scholars and researchers.

In this article, three important social enterprises together with their motives, processes and barriers are discussed. Each of these concepts is comprehensively described. Their conceptual designs are carefully laid out to explore similarities and differences. The goal is to illustrate that each social initiative has its own story written after crucial hurdles are successfully jumped. Within this context, as the essence of this article, the information about these three social enterprises is described and the three ventures are briefly compared. This article concludes with a final summary of the knowledge gained from this study.

\section{Defining Social Entrepreneurship}

Social entrepreneurship is a multidimensional model based on entrepreneurial activities with a social mission (Mort, Weerawardena \& Carnegie, 2003). It aims to achieve a long-term systematic social change by applying business/commercial approaches (Ersen, Kaya \& Meydanoglu, 2010). Individuals who criticize the existing social services and offer sustainable, innovative, financial, organizational or environmental solutions (Thake \& Zadek, 1997) are the foundation of social entrepreneurship.

However, social entrepreneurship as a social model may not have the same meaning for each group of people (Dees, 1998). Distinct forms may emerge in different places. This is because social entrepreneurship is a process in which con- ventional entrepreneurship is the initial focus of its actions, and socio-economic regulations, institutions and organizations can all impact social change missions (Fowler, 2000). Therefore, important factors for countries such as economical improvements or welfare levels have significant impacts on social transformation processes. It is clear that the development level in a country determines the level of comprehension of social entrepreneurship. Hence, it is important to note that arriving at a widely agreed upon definition of social entrepreneurship that draws upon common conceptions is quite difficult (Cho, 2006).

\section{Literature Review}

Social entrepreneurship is an academic field that provides important findings to individuals who aim to create social value. It has become a unique source for academic literature. Many projects and studies have been conducted for understanding and expanding the social entrepreneurship model. However, as it is reviewed in the further part of this paper, social entrepreneurship includes two components, i.e. "social" and "entrepreneurship". Moreover, social entrepreneurship has a dual perspective that social goals together with entrepreneurial goals are considered to reach a success.

The most significant characteristic of social entrepreneurs is defined as a purpose of social value creation. Their initial goals are to improve social profit and remove social disequilibrium (Boschee, 1998). Social enterprises gain value by their distinct approaches. Furthermore, the deficient social services attract social entrepreneurs' attention and become the initial step of their actions. Social entrepreneurs may focus on any kind of social problems (e.g., education, child labor, racism, etc.). Afterwards, they centralize these problem and they do not give up unless they reach their goals.

Conventional entrepreneurship is a process of discovering and pursuing commercial opportunities. The main purpose in conventional entrepreneurship is to create new businesses and increase financial profit. Also, conventional ventures pioneer the market activities, develop the economic levels and present numerous options to the customers. In this sense, conventional 
enterprises have a foundational meaning for social enterprises because social enterprises have a dual focus on both economic and social benefit. Hence, along with the social aspect, social enterprises also consider financial progress of their organizations. This approach is defined as the "double bottom-line" (Dees, 1998).

Today, social enterprises have to be adapted to the strong market competition and obtain a financial income. In addition to this, grant funding is also a problem that social enterprises encounter. This is because today grant funding stands as an increasingly competitive and demanding issue for social enterprises (Nicholls \& Cho, 2006). Therefore, this issue impacts economic progress of social organizations.

\section{The Main Elements of Social Entrepreneurship}

According to Austin (2006), there are three fundamental elements of social entrepreneurship: innovation, social value creation and loci. These are identified as the characteristics of social enterprises that are distinct from regular social ventures. Each of the terms is described below.

Innovation: An innovative way of thinking is essential to any kind of entrepreneurial activities. Although the primary goals of enterprises are to pursue opportunities and be effective in the long term, their innovational dimensions are the most critical component to reach these goals. In this respect, social entrepreneurship involves "social innovation" which is based on individuals' dissatisfactions with deficient social services (Ellis, 2010). Innovation is identified as the key element that social entrepreneurship emphasizes for social impact (Alvord, Brown \& Letts, 2002). Social entrepreneurship principally aims to create a social change. Thus, innovation, the most significant element, is applied in order to distinguish social entrepreneurship organizations from traditional social ventures. The innovational dimension of a social organization determines whether the ideas, processes, concepts or any other components that are used by an organization really create something new.

Social value creation: According to Spreckley (1981), an enterprise may have social goals as well as commercial objectives. In contrast, social entrepreneurship centralizes social value creation as its primary goal, thereby creating a remarkable change in society. Social value creation is defined as the core element separating social entrepreneurship from conventional entrepreneurship.

Loci: The emergence of social entrepreneurship does not require a particular context. It can emerge under any conditions and in any organizational structure. Because social entrepreneurship occurs as a result of collaborative interactions, it transcends all organizational concepts and sectors (Austin, 2006).

\section{Why Social Entrepreneurship is Important}

Social entrepreneurship as a rapidly growing phenomenon combines the terms "social" and "entrepreneurship". These two terms are obligatory for the entire model, fostering each other within the one common theoretical concept and invoking the interest of visionaries from both "social" and "entrepreneurial" perspectives.

However, in spite of the increasing interest in social entrepreneurship, its importance and understanding of the concept remain limited (Nicholls \& Cho, 2006) due to the lack of practical examples and empirical findings. Nevertheless, social entrepreneurship has achieved important changes, especially in developed countries, and thus its importance has become clearer. Furthermore, social entrepreneurs have applied effective methods such as innovation and cost-efficiency to alleviate social problems (e.g., poverty, gender inequality, health care, etc.) (Zahra, Eric, Neubaum \& Shulman, 2009). Thus far, traditional social venture solutions have been applied to social problems. But, there are some areas in which traditional social ventures are not effective. In comparison, social entrepreneurship, with its broader perspective, has provided many opportunities for individuals who work for the good of society. In this respect, social entrepreneurship is defined as a systematic change in which a variety of approaches can be taken (Said Scool, 2005). These approaches are identified as innovative, professional and sustainable, and they are needed to fill critical gaps in society. Summing up, many methods and systems have been created to respond to societies' apparent problems. 
Social entrepreneurship is certainly one of these methods. It is acknowledged that its social transformation, economical contribution and value creation achievements define it as a global social model.

\section{Analyzing Social Entrepreneurship Cases}

Studying social entrepreneurship requires detailed literature reviews. Based on the depth of the research, empirical or other academic research methods may be required to gain practical information and multi-dimensional perspective. In this section of the paper, the motives, processes and barriers of the selected social enterprise concepts are analyzed. Comparisons among the presented ventures are made. It is believed that this comparative study will contribute to social entrepreneurship literature and provide a useful perspective for future research.

\section{Analysis of Specialisterne}

Specialisterne is a Danish organization founded by Thorkil Sonne in 2004. It specializes in training and placing individuals with autism in productive and convenient jobs (one million jobs, 2014). Specialisterne is recognized as the first organization in the world to create a business model linking employers with potential employees struggling with an autism spectrum disorder. The concept and case of Specialisterne have been studied at many universities, such as Harvard Business School, and the organization has received numerous awards (Plattner, 2010).

\section{Motive of Specialisterne}

Autism is a heterogeneous condition that each autistic child or adult experiences differently (Lord, Cook, Leventhal \& Amaral, 2000). Autistic individuals have a different understanding of the things they experience and the world around them from that of non-autistic individuals. Fradd and Joy (2007, p. 9) mentioned in their report that the following symptoms are common in autistic individuals:

- Difficulties in speaking or repetitive use of language;

- Difficulty in understanding other people's emotions, body language or facial expressions;
- Limited interests and preoccupation with certain topics, such as trains or computers;

- A need of sameness and routines.

In addition to classic autism described above, there are other disorders recognized within the autism spectrum, such as Asperger syndrome, childhood disintegrative disorder and Rett syndrome (Fradd \& Joy 2007). In this respect, Specialisterne as a social enterprise mostly focuses on those who have high-functioning autism, referred to as Asperger syndrome. People with Asperger syndrome have more distinctive characteristics compared with those without autism. Most of them have average or above average IQs. Hence, Specialisterne's main objectives are to reveal their very specific skills, integrate them into appropriate job positions and support them in the society as independent individuals.

In a nutshell, people living with an autism spectrum disorder require a more sensitive and careful approach than average training provides. The training process and teaching methods are critical. In fact, Specialisterne's trainers and specialists are the foundation of the entire organization. They must be knowledgeable about both autism and a specific job. The superiors and trainers are bridges that connect autistic individuals to society. Individuals with high-functioning autism or Asperger syndrome often exhibit the following characteristics, which make them ideal candidates for certain types of jobs when given appropriate training (Specialisterne Operations, 2014):

- A high level of concentration;

- Perseverance for repetitive actions;

- Pattern recognition;

- The ability to spot any deviance in data, information, images and systems;

- Attention to detail;

- An outstanding memory;

- Process optimization.

\section{Process of Specialisterne}

Only a very small percentage of people with Asperger syndrome and autism is employed in the world. The founder of Specialisterne, Thorkil Sonne, made the following statement referring to this inequality: "a weed is a beautiful plant in an unwanted place. An herb is the same plant where it is wanted. Who decides if something is a weed or an herb? Society 
does." (as quoted in Bornstein, 2011). This quote points out that qualifications for employment are determined by people whose worldviews do not take into account the existence of autistic individuals and are shaped according to strict economic structures and the realities of our age. Therefore, unfortunately, discounting the needs of people living with autism or a disability is currently a common problem.

Nevertheless, Specialisterne sets its own goals which actually underlie the process path of the organization and give important hints about its intended direction as a social enterprise. According to Jensen (2011), Specialisterne has two countergoals: creating one million job opportunities worldwide and achieving a profit by operating as a social venture that cooperates with the for-profit sector. Their three-step expansion strategy outlined below was applied to achieve these goals:

1) Effectively present Danish Specialisterne to inspire individuals throughout the world and thus create international branches.

2) Collaborate with actors who have a common vision and expand the organization's concept through license agreements.

3) Establish and maintain efficient relations with the corporate sector.

As stated above, the initial goal of Specialisterne was to create an epidemic structure that provides one million job opportunities worldwide for people living with an autism spectrum disorder. To accomplish this goal, the process developed by Specialisterne had to be replicated in many locations throughout the world. One of the most significant indicators for a social enterprise is that the idea and process of the venture are implemented by other people from distinctive perspectives. The replication of Specialisterne clearly contributed to the organization's ultimate goals and makes it an example of unique social entrepreneurship.

\section{Barriers of Specialisterne}

As mentioned earlier, Specialisterne was established in Denmark in 2004. However, an initial barrier was encountered during the conception and establishment process by the founder, experts, trainers and all significant people within the organization. Denmark is a Scandinavian country with a high welfare level and a higher standard of living than is found in many societies in the world. The governmental policies and economic regulations are carefully and strictly implemented. Therefore, Thorkil Sonne (Pieroni, 2014) was careful to note that an initial barrier might be the fact that Danish citizens pay high taxes to support government programs that are effective in many ways. When he initially proposed his idea, people did not understand the purpose. They questioned his reason for attempting to create a social enterprise because by using tax income, the government already provided social services and training for those with autism. Eventually, he expressed his appreciation to all of the media channels that supported the spread of the Specialisterne idea and helped to remove this barrier.

Another important barrier is that although Specialisterne operates as a social enterprise with a social purpose, it also operates for financial profit. Because it cooperates with for-profit organizations and companies, Specialisterne must provide high quality IT services by considering all existing market competition and rules. In this context, a dilemma arises regarding what information can be distributed to other branches because some information must be kept confidential to sustain its competitive advantage in the market (Jensen, 2011).

\section{Analysis of the Grameen Bank}

The Grameen Bank was founded by economist Professor Muhammad Yunus in Bangladesh in 1976. The Grameen Bank was created to reduce poverty among Bangladeshi people, and it applied quite unusual banking methods. The most distinct and well-known approach of the Grameen Bank was to offer small loans to extremely poor people in the region. With these loans, many poor people were able to create their own businesses and generate income, allowing them to cross the poverty line, which was the primary goal of the Grameen Bank. The first money lent by Yunus was 27 dollars to 42 stool makers, and since then, the Grameen Bank has increased in capacity and scale. Today, the Grameen Bank is a worldwide organization with over 5.5 million members and more than 5 billion dollars in dispersed loans (Sengupta \& Aubuchon, 2008). 


\section{Motive of the Grameen Bank}

While conducting research about the Grameen Bank, it is impossible to miss the name of Muhammad Yunus. In addition to being one of the most well-known social entrepreneurs in the world, he is the father of the microfinance system and the founder of the Grameen Bank, and in 2006, he was awarded the Nobel Peace Prize (Nicholls, 2006).

Prof. Yunus is a good example of a farreaching engineer. Due to the extremely high poverty level in his home country of Bangladesh, he decided to attempt to alleviate poverty. To do so, he focused on changes that challenged conventional thinking about entrenched institutions. He was however aware of the fact that such changes were limited to external attempts rather than changes within the existing system (Zahra et. al., 2009). Yunus achieved this social transformation by establishing the Grameen Bank in Bangladesh in 1976. The name was actually inspired by the Bengali word "gram", which means village, and the word "Grameen", which refers to poor people living in a village (Mainsah, Heuer, Kalra \& Zhang, 2004).

The Grameen Bank has become a unique source of help for the people in need in Bangladesh. It has supplied small loans to poor people who would not have been considered as regular customers by other banks. The Grameen Bank and Muhammad Yunus have achieved success on a global scale, and the model of the Grameen Bank has inspired similar processes in many other countries (Mair, 2008).

\section{Process of the Grameen Bank}

The Grameen Bank created a new model that was based on large-scale "micro-lending" credits received by the poor. It became an efficient internationally respected institution used to reduce poverty (Brock \& Ashoka, 2008). Its process and the distinctive implementation of modern banking methods lie behind the success of the Grameen Bank. Seelos and Mair (2005) stated that the Grameen Bank's micro-lending system differs from regular bank loans in three aspects:

1) The main structure must be protected to ensure successful loan payment. The design of the system is a priority in the structure.

2) Only people without land and the poorest villagers are allowed to apply for loans.

3) The Grameen Bank sets a high priority on lending to women who are socially and economically vulnerable. This is one of the most distinct characteristics of the Grameen Bank.

In their lending to women, the Grameen Bank dispensed with the requirement of collateral for a loan, a concept unthinkable in the modern banking system. The Grameen Bank considers rural women to be entrepreneurs, and thus the loans are given to them without any collateral. This policy actually prevents further critical problems from developing during the repayment process. This strategy was developed by considering cultural characteristics. In this region, women are honored among families, and they represent the families in the society. If a loan is not repaid, the woman is publicly shamed, causing her family disgrace. Hence, 98 percent of the no-collateral loans were successfully repaid (Karim, 2008).

As a result of the micro-lending system, the Grameen Bank has offered loans to over 7.5 million people, and 97 percent of people who received loans are women. As an indicator of the Grameen Bank's success, 68 percent of the families who received a loan moved out of the poverty (Yunus, Moingeon \& Ortega, 2010).

\section{Barriers of the Grameen Bank}

Although the Grameen Bank has made significant achievements in Bangladesh and worldwide, like many social ventures, it has also experienced some challenges. One problem is related to funding. The Grameen Bank relies on international donors for financial support. As the bank expands its activities, its dependency on external funding grows as well (Rahman 1988).

Moreover, due to the Grameen Bank's global success, there are too many replications, which create additional pressure on the Grameen Bank (Auwal \& Singhal, 1992). Today, poor management of these banks mimicking the Grameen Bank has resulted in losses that are associated with the Grameen Bank, damaging its image. 
Although the media and other social movements have supported the Grameen Bank in the past, the bank and micro-finance system in general have come under serious criticism for lack of financial results and transparency (Mainsah et. al., 2004).

\section{Analysis of Sekem}

The Sekem was founded by Dr. Ibrahim Abouleish in 1977. It was established to support the sustainable development of the individual, both socially and culturally, through entrepreneurial activities. Sekem operates its initiatives in various sectors, and each of these initiatives has large-scale impacts. It consists of several companies according to characteristics of the fields. Sekem's products include fresh fruit and vegetables, herbs and spices, organic foods and beverages, organic cotton and textiles and pharmaceutical products. There are currently seven companies under the roof of the Sekem Group: Libra, Mizan, Hator, Lotus, Isis, Atos, and Nature Tex (Hatem, 2007). These companies are responsible for pioneering work in their related sectors.

\section{Motive of Sekem}

Ibrahim Abouleish, a chemical engineer and medical scientist, worked in Austria for 21 years. After his career abroad, he was inspired to improve the social and economic conditions of his home country. Thus, he returned to Egypt to create a business with the goal of improving the economy and creating sustainable social change. With this purpose in mind, he established Sekem in 1977. The name of the institution is an old Egyptian word meaning "vitality from the sun" (Almohsen, 2014).

Sekem is a multi-business institution that constantly supports its umbrella companies. With its creation of social, cultural and economic value through its support and funding, Sekem has had a large impact on Egyptian society. Today, Sekem is globally recognized as a successful social enterprise with international value. In 2003, Dr. Abouleish was awarded the Right Livelihood Award, which is given by the Swedish Parliament and is referred to as the "Alternative Nobel Prize".

\section{Process of Sekem}

Sekem has grown out of the social and economic grounds in Egypt and become an organization that has won peoples' confidence with its long term impacts. Sekem profits from its businesses and it can therefore financially support institutions such as medical centers, adult education centers and schools. Moreover, Sekem fills the institutional gaps in Egypt by creating distinctive businesses that cater to the basic needs of Egyptian society (Seelos \& Mair, 2005).

Sekem primarily focuses on the improvement of organic and biodynamic agriculture. It has pioneered a new system for planting in Egypt. Additionally, Sekem has conducted remarkable research to increase crop yields and improve soil fertility. The new innovative agricultural systems that Sekem adopted resulted in significant agricultural outcomes. One of the most important successes of Sekem's modern farming methods is in protection of the cotton plant. Sekem reduced the use of fertilizers and synthetic pesticides in Egypt by approximately 90 percent, from 35,000 to 3,000 tons per year (Almohsen, 2014).

Sekem has caused significant transformation in several areas, leading the way in organic agriculture, education and medical care. It has over 2,000 employees, whose rights, beliefs and genders are equally considered and protected. Sekem has been a productive and innovative source, linking more than 3,000 farmers who produce Sekem's products and benefit from Sekem's sustainable concepts. Moreover, Sekem's medical center, which provides holistic medicinal approaches to therapy, treated 4,000 employees and 30,000 people from throughout Egypt in 2011. In addition, as an organizational strategy, 10 percent of Sekem's profits are used to support social development projects.

\section{Barriers of Sekem}

With the remarkable success of its businesses, structure and community development projects, Sekem has become an inspiration for surrounding societies. Its non-traditional emphasis on social responsibility has raised awareness of sustainable organic agriculture. Nevertheless, despite its great achievements, Sekem encountered many tough issues along the way. 
One of the difficulties that Sekem encountered was bureaucratic procedures. Inefficient governmental regulations and cumbersome bureaucracy obstructed the spreading of Sekem to some extent. For example, Sekem sought to obtain an organic product certificate as a proof of its compliance with organic regulations. But, the request was not answered in a timely manner. Moreover, due to the inadequate governmental services such as poor supply of electricity, poor transportation, and lack of some vital regulations, Sekem experienced many difficulties running its initiatives. In addition, initially, the organization was not financially supported by banks. Although Mr. Ibrahim eventually overcame this obstacle, it was not easy to obtain bank loans for the fields in the desert (Hatem, 2007).

Finally, the political status of the country also created a barrier. Like many social entrepreneurs and social enterprises, Sekem was also affected by governmental policies. Some external powers with antidemocratic goals ignored the existence of Sekem. The most tragic example of a governmental barrier was the military occupation of the first fields of Sekem (Seelos, Mair, Battilana \& Dacin, 2010).

\section{Comparison}

In the previous part of the paper, three successful social enterprises were introduced to illustrate their main organizational structures and backgrounds. This section presents a comparative account that is derived from the examination of the three social ventures.

As can be seen in table 1, the strengths and weaknesses of the social ventures are analyzed through the encountered barriers. It is clear that demand is a significant factor among the strengths listed for each initiative (in the table, it appears as "specific interests" for Specialisterne, "needs of the individual initiatives" for the Grameen Bank, and "lack of modern farming" for Sekem). For example, Specialisterne's main purpose is to support autistic people. Thorkil Sonne decided to pursue the Specialisterne idea because he had an autistic child. In the same way, specific demand also occurred in the Grameen Bank case. Muhammad Yunus hailed from a society where the people were trapped in poverty. Hence, he sought solutions to alleviate pov- erty, creating the Grameen Bank model. In a similar pattern, Ibrahim Abouleish, founder of Sekem, realized the inefficient production methods and lack of fertility in Egyptian farming. Using the educational knowledge he gained in Europe, he became a pioneer and even a teacher for farmers rather than an entrepreneur.

The emphasized factors indicate that specific demands must appear to begin a social enterprise. Moreover, these demands can be identified as bilateral, connecting the social entrepreneurial soul with the problem in the community. In brief, Yunus's inspiration was the community he was in, Abouleish's was the land of his home country and Sonne's was his son's autism. Each social entrepreneur has his own inclination and sensitivity. Thus, social entrepreneurs focus on society's needs and try to meet these needs in a meaningful way by the solutions they offer.

If one focuses on the strengths of these social enterprises, it is clear that the social initiatives are strongly associated with their leaders, bringing potentially positive and negative results. Hence, this matter can be categorized as both a strength and a weakness. The negative result is mostly related to an organization's image. Leaders are often well recognized individuals, and the public can lose sight of the important achievements and improvements of an organization when the primary focus is on the leader. This situation is most apparent in the Grameen Bank model. Muhammad Yunus's successes and global awards (especially the Nobel Peace Prize) were in the forefront of people's mind more so than the Grameen Bank itself, consequently causing some questions regarding the future of the organization without Yunus. For example, questions such as "Who will represent the Grameen Bank after Yunus?" "Can the Grameen Bank continue to succeed without Yunus?" and "Is the organization strong enough to sustain its existence without a global pioneer?" were raised. However, being led by a global figure can also be a significant asset to a social enterprise. Challenging issues such as funding, marketing and advertising can be easily overcome by the support of a well-known leader. As described previously, Sekem encountered some financial barriers with the banks; however, the problems were overcome with the personal involvement of Abouleish. 


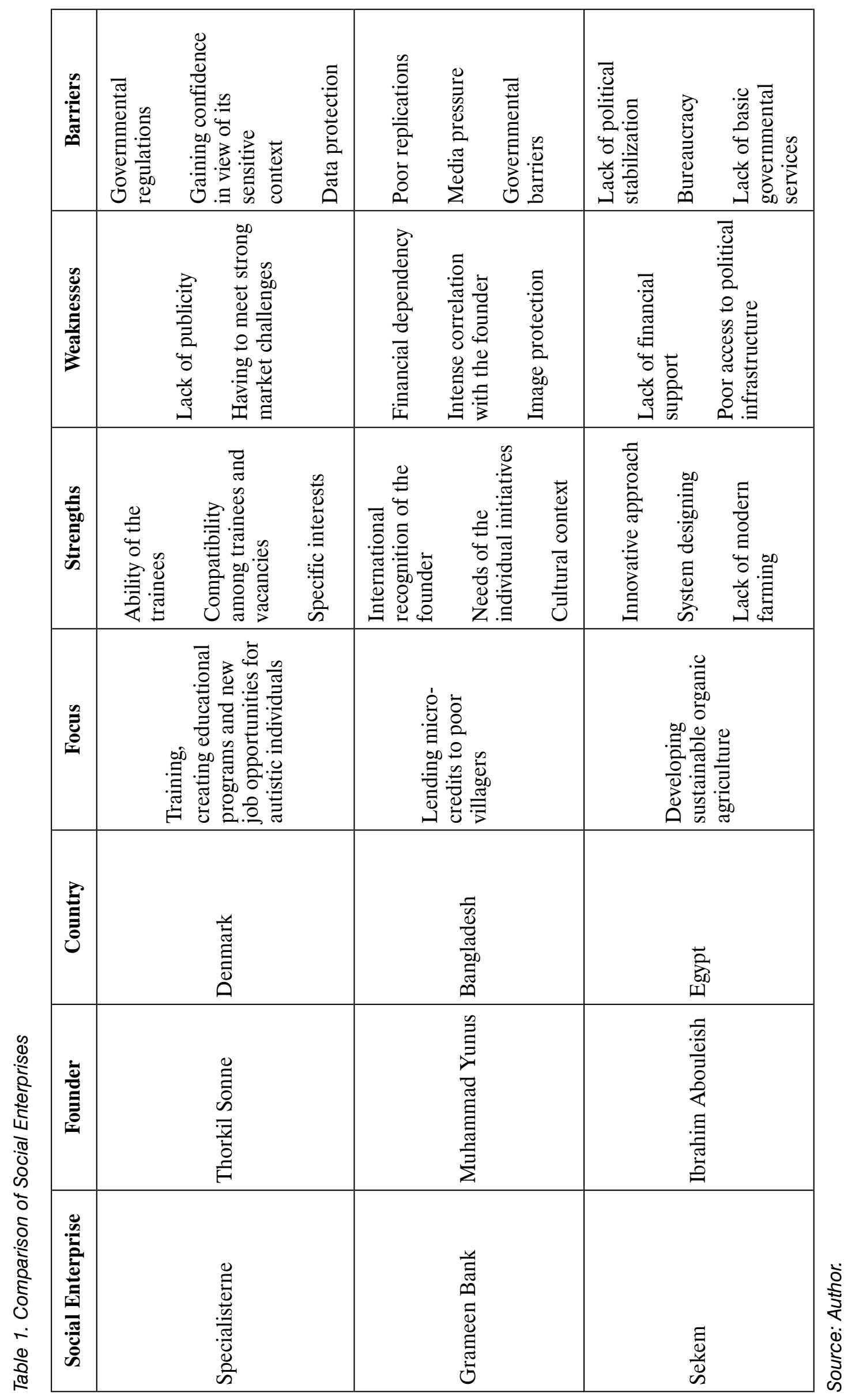


The most effective strength of Specialisterne is the ability of their trainees. Because Specialisterne mostly focuses on software technology, the trainees with Asperger syndrome, who have some mental advantages over their non-autistic counterparts, are able to meet all the necessary job requirements after proper training. According to employers, their strengths satisfy the existing needs of companies. Therefore, Specialisterne as a social enterprise sustained its success and it did not fail in the difficult and constantly developing technology market. In contrast with Specialisterne, Sekem began with the purpose of pursuing innovative strategies. Sekem implemented new techniques and technologies to increase agricultural profit. The importance of organic agriculture was presented to the farmers, helping farmers and others in Egypt envision a new agricultural system. One of the most significant strength patterns for the Grameen Bank was the cultural context, especially during the establishment process and initial progress. Yunus decided to use the fact that women have a higher place of honor in Bangladesh than men to achieve a positive outcome. As a result, the Grameen Bank model successfully emerged with a large-scale positive impact, and most of the loans made without collateral were repaid.

The reason for Specialisterne's weaknesses are general barriers for social enterprises as well. Although Specialisterne operates in many countries, it struggles to be adapted to new technological developments. Additionally, it carries out its activities based on economic outcomes. Therefore, it must compete with powerful competitors in the market. The gained knowledge and data must be carefully protected to create a competitive advantage. Additionally, because autism is a sensitive subject, some difficulties are experienced in the process of building trust with the families of autistic individuals. However, thanks to the work of Specialisterne, progress has been made in overcoming this issue. Finally, the most important barrier for many social ventures is governmental barriers. This is especially true in countries where nonprofit, not-for-profit and governmental organizations are not distinguished or clearly regulated by the law. Despite the humanitarian purposes of social organizations, they can be easily accused of generating illegal revenue if their concepts are not officially described. The Grameen Bank and Sekem experienced similar problems with the government. Sekem strove to protect itself against the unstable politics, corruption and military coups in Egypt. The government's inability to provide very basic public services such as water and electricity, which are essential for farming, created difficulties for Sekem.

The Grameen Bank's obvious weakness is its organizational image. Many banks and companies throughout the world developed similar micro-lending systems. However, the Grameen Bank was created to alleviate poverty and provide new opportunities for poor people, not to provide financial income for the bank. It was simply intended as a social benefit. In contrast, not all of the replications had the same goal and some of these banks failed. Unfortunately, some of the negative impressions created by these replications were associated with the original Grameen Bank, changing people's perceptions and causing criticism of the Grameen Bank and its efficiency.

\section{Conclusion}

This paper opens up an avenue of research by providing a comparative analysis for comprehending social entrepreneurship. The analysis reveals that social entrepreneurship takes form according to the content of the initiative. Each social organization struggles with specific issues, and each of these issues is addressed in a distinct way. Moreover, social entrepreneurial skills are needed most during a crisis, when specific solutions are sought. While looking at the progress of the examined social ventures, it is clear that some of the problems experienced by the social ventures are similar or even identical. One common issue may affect all of the initiatives, but clearly there is no single solution that can be generalized to or implemented by all organizations. Economic, social, political, and cultural factors must be taken into account by each social enterprise. It is believed that this article will help to consolidate social entrepreneurship literature, serving as a useful source of information for answering additional questions. 


\section{References}

Almohsen, R.A. (2014). Linking research and local people through organic agriculture. Paris: UNESCO, the Islamic Development Bank.

Alvord, S.H., Brown, D.L. and Letts, C.W. (2002). Social Entrepreneurship and Social Tranformation. Harvard Univeristy. Boston: The Hauser Center for Nonprofit Organization and Kennedy School of Geovernment.

Austin, J.E. (2006). Three Avenues for Social Entrepreneruship Research. In: J. Mair, J. Robinson and K. Hockerts (eds.), Social Entrepreneurship (pp. 22-33). New York: Palgrave MacMillan.

Auwal, M.A. and Singhal, A. (1992). The diffusion of Grameen Bank in Bangladesh: Lessons learned about alleviating rural poverty. Knowledge: Creation, Diffusion, Utilization, 14(1), 7-28.

Bornstein, D. (2011). The Opinion Pages. Retrieved from: The New York Times: http:/opinionator. blogs.nytimes.com/2011/06/30/putting-the-gifts-ofthe-autistic-to-work $/ ? \_$php $=$true\&_type $=$blogs \& $\mathrm{r}=0$ \# (14.05.2014).

Boschee, J. (1998). Merging mission and money: $A$ board member's guide to social entrepreneurship. Retrieved from: http://www.socialent.org/pdfs/MergingMission.pdf.

Brock, D.D. and Ashoka. (2008). Social Entrepreneurship: Teaching resources handbook for faculty engaged in teaching and research in social entrepreneurship. Retrieved from: http://papers.ssrn.com/ sol3/papers.cfm?abstract_id=1344412.

Cho, A.H. (2006). Politics, Values and Social Entrepreneurship: A Critical Appraisal. In: J. Mair, J. Robinson and K. Hockerts (eds.), Social Entrepreneurship (pp. 34-56). New York: Pelgrave Macmillan.

Dees, J.G. (1998). The meaning of "Social Entrepreneurship". Kauffman Center for Entrepreneurial Leadership, 1-5.

Ellis, T. (2010). The New Pioneers: Sustainable Business Success Through Social Innovation and Social Entrepreneurhsip. West Sussex: John Wily \& Sons.

Ersen, T.B., Kaya, D. and Meydanoglu, Z. (2010). Social Enterprises and Turkey. TUSEV. Istanbul: TUSEV, British Council.

Fowler, A. (2000). NGDOs as a moment in history: Beyond aid to social entrepreneurship or civic innovation? Third World Quarterly, 21(4), 637-654.

Fradd, A. and Joy, I. (2007). A Life Less Ordinary: People with Autism, A Guide for Donors and Funders. London: Lloyds TSB Foundation for Scotland. Retrieved from: http://socialwelfare.bl.uk/subjectareas/services-client-groups/adults-disabilities/ newphilanthropycapital/142270A-life-less-ordinaryFULL1.pdf.
Hatem, T. (2007). Sekem: A holistic Egyptian initiative. New York: United Nations Development Programme.

Jensen, N.E. (2011). Specialisterne, changing standarts. Copenhagen: Copenhagen Business School. Retrieved from: http://studenttheses.cbs. dk/bitstream/handle/10417/3508/nanna_nicoline_ elkj\%C3\%A6r_jensen.pdf?sequence $=1$.

Karim, L. (2008). Demystifying micro-Credit: The Grameen Bank, NGOs and neoliberalism in Bangladesh. Cultural Dynamics, 20(1), 5-29.

Lord, C., Cook, E.H., Leventhal, B.L. and Amaral, D.G. (2001). Autism Spectrum Disorders. In: S. Hyman (ed.), The Science of Mental Health (pp. 217-225). New York: Routledge.

Mainsah, E., Heuer, S.R., Kalra, A. and Zhang, Q. (2004). Grameen Bank: Taking Capitalism to the Poor. Chazen Web Journal of International Business, $1-28$.

Mair, J. (2008). Social Entrepreneurship: Taking Stock and Looking Ahead. IESE Business School. World Entrepreneurship Forum.

Mort, G.S., Weeravardena J. and Carnegie, K. (2003). Social entrepreneurship: Towards conceptualization. International Journal of Nonprofit and Voluntary Sector Marketing, 8 (1), 76-88, http:// dx.doi.org/10.1002/nvsm.202.

Nicholls, A. (2006). Endnote. In: A. Nicholls (ed.), Social Entrepreneurship: New Models of Sustainable Social Change (pp. 407-412). New York: Oxford University Press.

Nicholls, A. and Cho, A.H. (2006). Social Entrepreneurship: The Structuration of a Field. In: A. Nicholls (ed.), Social Entrepreneurship: New Models of Sustainable Social Change (pp. 99-118). New York: Oxford University Press.

One million jobs. (2014). Retrieved from: http:// specialistpeople.com/about/one-million-jobs/ (29.07.2014).

Pieroni, A. (2014). Specialisterne: A Denmark Social Enterprise, Aims to Provide Jobs to 1 million Autistic People. Retrieved from: Social Story: Inspire Innovate Ignite: http://social.yourstory.com/2014/03/specialisterne-soren-thorkil-autistic-jobs/ (10.06.2014).

Plattner, M. (2009). Autistic persons love the notty gritty. (M. Benedetti, Trans.). Retrieved from: MyHadicap: Information and community for people with diabilities: http://www.myhandicap.com/specialisterne-autism-handicap.html?PHPSESSID =e01e297380a19a34c85119694000ead3 (01.08.2014).

Rahman, A. (1988). Alleviation of rural poverty: Replicability of the Grameen Bank model. South Asia Journal, 1 (4), 86-475.

Said, School. (2005). Retrieved from: Skoll Centre for Entrepreneurship: http://www.sbs.ox.ac.uk/ideas-impact/skoll (03.08.2013). 
Seelos, C. \& Mair, J. (2005). Social entrepreneurship: Creating new business models to serve the poor. Business Horizons, 48, 241-246, DOI:10.1016/j.bushor.2004.11.006.

Seelos, C., Mair, J., Battilana, J. and Dacin, T.M. (2010). The embeddedness of social entrepreneurship: Understanding variation across local communities. Navarra: IESE Business School-University of Navarra.

Sengupta, R. and Aubuchon, C.P. (2008). The Microfinance Revolution: An Overview. Federal Reserve Bank of St. Louis Review, 90 (1), 9-30.

Specialisterne Operations. (2014). Retrieved from: Specialist People Foundation: http://specialistpeople.com/about/specialisterne/specialisterne-licensees/ (02.06.2014).

Spreckley, F. (1981). Social Audit - A Management Tool for Co-operative Working. Leeds: Beechwood
College. Retrieved from: http://www.socialauditnetwork.org.uk/files/3113/2325/3650/Social_ Audit_1981.pdf.

Thake, S. and Zadek, S. (1997). Practical people, noble causes. How to support community based social entrepreneurs. London: New Economic Foundation.

Yunus, M., Moingeon, B. and Ortega, L.L. (2010). Building social business models: Lessons from the Grameen Experience. Long Range Planning, 308-325, http://dx.doi.org/10.1016/j. lrp.2009.12.005.

Zahra, S.A., Gedajlovic, E., Neubaum, D.O. and Shulman, J.M. (2009). A typology of social entrepreneurs: Motives, searches process and ethical challenge. Journal of Business Venturing, 519-532, http://dx.doi.org/10.1016/j.jbusvent.2008.04.007. 